\title{
AESTHETIC EXPERIENCE IN THE NATURE-CULTURE CONTINUUM. THE BIOLOGICAL DIMENSION OF PRAGMATIST AESTHETICS
}

\section{A B S T R A C T}

In 1930 American pragmatist philosopher John Dewey introduced into aesthetics a relatively new idea of experience. Living in modern time Dewey offered non-modernist way of thinking which especially in the field of aesthetics seems to be more adequate to our time than the modern ideas of aesthetic experience and autonomy of art. After short presentation of Dewey's philosophy of aesthetics I would like to show its inner dimensions that are fully developed today: ecological, evolutionary and transhuman tendencies, experience as interaction, soma and sensuous perspective. 


\section{PRAGMATIST AESTHETICS AND SOMAESTHETICS}

Pragmatist aesthetics is associated with the name of Richard Shusterman, for he was the person who published a book of this title in 1992, offering in it an outline of the whole conception. Never before had a book with this or a similar title been published and - despite an increasing interest in pragmatism and pragmatist aesthetics - no larger work that could compete with that by Shusterman has been published since. However, a lot of articles of detailed works developing particular threads of pragmatist aesthetics have been published all over the world.

Nevertheless, pragmatist aesthetics, though bearing a different name and not offered as a whole project had been in existence before Shusterman, implicitly included in pragmatist philosophy, and in particular in John Dewey's philosophy of experience and philosophy of art. In his book Shusterman himself indicates Deweyan roots of his aesthetics.

Shusterman's somaesthetics constitutes an integral part of his project of pragmatist aesthetics. Somaesthetics refers to man's corporeality (soma) and sensuality. Like Dewey, Shusterman opposes the main trend of European philosophical thought based on duality, in which consciousness was separated from body and the subject was identified exclusively - to put it in Cartesian way - as res cogitans. Reaching deep into the sources of ancient Greece and Orient (Confucius) and later appraising critically European philosophy, Shusterman identifies those thinkers who spoke up for carnality pointing at the identity of the mind and the body, that is, consciousness and matter. Among those thinkers he found also American pragmatists and, in particular, John Dewey.

In his somaesthetics Shusterman deals exclusively with body of a human being. My goal is to indicate that Dewey's philosophy of pragmatist aesthetics allows for developing certain threads of thought concerning art and the recipient of art - the thought going beyond the sphere of this which is human. And the 'nonhuman' sphere does not signify the divine sphere or even the angelic one. Just the opposite - it is directed at biology and the theory of evolution. It is not above, but rather below everything that is human. Dewey's aesthetics and his conception of aesthetic experience are open to all dimensions of the world of nature.

My interest in this part of Dewey's thought was undoubtedly evoked by the new trends in research that have occurred in aesthetics within the last decades. Works on animal aesthetics as well as works in the area of evolutionary 
aesthetics have been published. Their authors do not tend to refer to Dewey. I believe that the considerations included in the book Art as Experience fully correspond to the above mentioned trends in research, introducing - at the same time their own specific character rooted in Deweyan naturalism.

\section{RECONSTRUCTION OF JOHN DEWEY'S PHILOSOPHY OF EXPERIENCE}

I shall now proceed to reconstruct Dewey's thought. ${ }^{1}$ In numerous works regarding his philosophy the authors emphasize that Dewey was born in the year when Charles Darwin's book On the Origin of Species was published (1859). Obviously, being born in that year was a chance situation, but it is no longer by chance that Dewey's book totally devoted to 'philosophy of aesthetics' starts with two chapters dealing with a 'live creature'. I wish to emphasize that this is highly characteristic and significant; I know no other book on aesthetics and, the more so, in the tradition of this discipline it would be hard to imagine a book that would start with this concept and this kind of problems.

In those two starting chapters, the leading concepts are those of life and of experience that is treated as a portion, as an emerging particle of the process of living, characterized by an interaction of a living creature with its environment or, more broadly - as Dewey puts it - 'the energies of the organism with those of the conditions under which it lives."

It should be remembered that in Dewey's conception experience may take place also below the level of life, where interactions between different forms of energy take place. Nevertheless, Dewey is focused not so much on the physical level of experience as on the biological one, in which it is a live creature that takes part in the interaction. The concept of a 'live creature' (also an organism) is obviously broader than that of a 'human being '; it also includes representatives of flora and fauna, and Dewey admits a possibility of experience as an interaction between plants and their surroundings (heliotropism) as well as between animals and their environment. Finally, however, the live creature in the center of Dewey's attention is, first of all, a human being for it is the only individual aware of participation and interaction that experience involves. It is worth stressing that in Dewey's naturalism there is no gap between humans and other forms of life; just the contrary, there is continuity embodied also in the continuity of experience. There is also continuity between a live being and its surroundings and the differentiation is merely an indication of various aspects of experience. 
'The nature of experience is determined by the essential conditions of life. While man is other than bird and beast, he shares basic vital functions with them and has to make the same basal adjustments if he is to continue the process of living. Having the same vital needs, man derives the means by which he breathes, moves, looks and listens, the very brain with which he coordinates his senses and his movements, from his animal forbears. The organs with which he maintains himself in being are not of himself alone, but by the grace of struggles and achievements of a long line of animal ancestry.'

And Dewey concludes: 'These biological commonplaces are something more than that; they reach to the roots of the esthetic in experience."'3

\section{BIOLOGICAL DIMENSION OF DEWEY'S AESTHETICS}

What does the aesthetic mean in this context? It means a harmony of interactions between a living being and its surroundings. This harmonious interaction acquires the name 'an experience' and its indicator is 'aesthetic quality' permeating the experience. Although Dewey does not do it explicitly, we could speak of the beauty of the process of experience. This experience is possible on all levels of nature; what is more, sometimes the harmony of interaction with the surroundings is easier to achieve on the level of animals than that of humans, which was due to many causes. One of the most important causes is the specific attitude to carnality and sensuality worked out in the western philosophical thought.

Dewey posed a fundamental question before the Western philosophical tradition: 'Why is the attempt to connect the higher and ideal things of experience with basic vital roots so often regarded as betrayal of their nature and denial of their value?"' $\mathrm{H}$ He claimed that in order to answer this question one must examine 'the conditions that have brought about contempt for the body, fear of the senses, and the opposition of flesh and spirit', the conditions in which 'sense and flesh get a bad name"".

Dewey wrote: 'To grasp the sources of esthetic experience it is, therefore, necessary to have recourse to animal life below the human scale. (...) The live animal is fully present, all there, in all of its actions: in its wary glances, its sharp sniffings, its abrupt cocking of ears. All senses are equally on the qui vive. As you watch, you see motion merging into sense and sense into motion - constituting that animal grace so hard for man to rival. What the live creature retains from the past and what it expects from the future operate as directions in the present." $"$ 
I have executed a reconstruction of Dewey's thought concerning the basis of aesthetic experience which, in order to be understood, requires getting below the level of the human and considering what an interaction of an animal with its surroundings consists of. Now I would like to show, by way of example, what specific features may be introduced by Dewey's conception into the currents of evolutionary aesthetics developed today.

\section{CRITICAL ANALYSIS OF WOLFGANG WELSCH'S “ANIMAL AESTHETICS” FROM THE PRAGMATIST PERSPECTIVE}

Let us start with aesthetics of animals. During the Congress of Aesthetics in Rio de Janeiro (2004) Wolfgang Welsch presented a paper entitles 'Animal Aesthetics". 7 Opposing the anthropocentric character of modernist aesthetics Welsch perceives the need for a turn towards trans-human aesthetics conceiving the man and his problems in the cosmic perspective, that is, in the perspective of the whole nature. There occurs a fundamental question: Did the aesthetic attitude - experiencing the pleasure of beauty - develop only within the human culture or does it have its foundations in the animal world as well? An attempt at answering this question directs us to the theory of evolution.

[Remark: animal aesthetics does not refer to so called animal art. Of course, the animal aesthetics does not mean 'aesthetics created by animals', it would be a nonsense. The animal aesthetics consists in putting the main aesthetic concepts and questions in relation to the non-human species.]

Welsch criticizes the previous achievements of evolutionary aesthetics, accusing it of supporting the anthropocentric approach in which it is preDarwinian for it recognizes the 'infinity of the difference between the humans and the animals'. He claims:

'Darwin initiated the subject of evolutionary aesthetics. He did so by providing an account of animal aesthetics. The current champions of evolutionary aesthetics, however, mistrust and even demolish his concept. While Darwin had advocated the existence of a genuinely aesthetic sense in some animals, most contemporary evolutionists reduce the aesthetic to mere survival value'.

Welsch tries to outline the foundations of evolutionary aesthetics through a return to Darwin's writings and their new and thorough reading.

Welsch's considerations are subtle and ultimately they lead to the following conclusions: In accord with Darwin we should accept continuity between the human and animal aesthetics and search for the moment at which the correlation 
between beauty and the sense of beauty occurred. We could distinguish the following phases:

- pre-aesthetic beauty (stripes, shades and patterns on the body devoid of aesthetic implications);

- proto-aesthetic beauty (colors of flowers and fruit, 'attracting attention'; 'striking the eye', which signifies orientation at building certain relation attracting insects and birds to achieve pollination);

- beauty in its proper meaning directed at the aesthetic sense; this beauty occurs within a single species, in the intersexual relation - the beauty of a male is addressed at the sense of beauty of a female. And although here we are entangled in the context of sexual selection and reproduction, Welsch - in accord with Darwin - treats this kind of beauty as aesthetic beauty - the beauty in itself. For we have to do here with enchanting the females with the ornaments possessed by the males (and these ornaments, like deer antlers, are not only useless but, in fact they make the struggle for survival more difficult, for example during the flight from danger in a forest); the females make an aesthetic choice - a choice of the most attractive male.

Welsch claims: When females opt for more attractive males their choice is based on aesthetic judgment, which, in turn, is rooted in their 'taste of beauty'. Welsch admits: "Aesthetic judgment' is my term, not Darwin's; but I am confident it grasps and faithfully represents his idea'. What is more, aesthetic evaluation is based on pleasure, the appearance of a male triggers the sensation of pleasure and the more beautiful it is the greater the pleasure. Although it is sexual energy that provokes this relation, the issue of usefulness connected with sexual selection and reproduction is pushed to the background and the issue of beauty in itself evoking the pleasure of aesthetic nature comes to the lead. Welsch writes: 'Yet there is strong evidence that the females do perceive the beautiful as such. With peacocks, for instance, a slight variation of the beautiful ornaments can already reduce or even ruin the chances of mating'. And he adds that no proof has been found that a change in ornaments might be connected with a reduction of fitness. Thus the causes of rejection would be purely aesthetic.

Accepting the principle of continuity that is fundamental for evolution, which states that higher stages are always formed on the basis of lower stages and cannot be understood without them, Welsch supports the thesis that the beginnings of the aesthetic sense and aesthetic evaluation already appeared in the world of animals. Although his approach differs from the attitudes assumed 
within the neo-Darwinian and socio-biological currents where the aesthetic is reduced to the issue of survival and beauty to fitness, Welsch's considerations follow intentionally the same kind of discourse that was designated by Darwin. Its aim is to determine whether the perception of beauty for its own sake does occur in the world of animals or whether it serves only natural and sexual selection and therefore does not attain the aesthetic character. According to Welsch beauty may lead to achievement of various goals, but the condition of achieving them is perception of beauty as such.

Welsch's considerations over the aesthetics in the world of animals are marked by the terms like: beauty in itself, the aesthetic understood as free of usefulness, aesthetic attitude as orientation at perception of beauty in itself. These are concepts of modern aesthetics, which cannot be fully applied to the earlier phases in the development of art and aesthetics in human history. The closest higher stage, comparative to the level of animals, should be rather a reconstruction of human aesthetics at the initial stages of its development. But at those earliest stages art and beauty were not separated from usefulness and practical goals.

My doubts, however, are of more fundamental nature. Should we - while asking about the aesthetics of animals - focus our considerations on beauty? Is the language of Darwin's theory the only option that allows us to perceive the continuity of the development of aesthetic experiences on the subsequent levels of nature?

Let us now return to Dewey. His philosophy is based on the ideas of continuity and continuation, which puts it close to the theory of evolution. Nevertheless, the central concept of Dewey's aesthetics is not beauty (he hardly ever mentions this concept, using the term 'aesthetic quality'), but experience understood as 'an experience' of aesthetic character. This experience is not opposed to other life experiences; it is one of them, if certain conditions are satisfied. These conditions, however, do not include liberating the experience of practical, cognitive or any other goals. The aesthetic and the useful do not oppose each other in the conception of the American pragmatist.

Let us recall once again the broadest definition of experience in Dewey's conception: it is an interaction between different kinds of energy. Detailed description of the kinds of energy entering the interaction allows us to place the occurring experience on the appropriate level of the continuum natureculture. So, as regards the above quoted considerations of Welsch concerning 
the relation between a female and a male, in which the pleasure of perceiving beauty and the aesthetic appreciation take place, Dewey would describe this situation in a different way, using his own terminology. He would understand the relation between the female and the male as an interaction between the sexual energies represented by the masculine party and the feminine one, between which the tension arises. If the course of the interaction is rhythmic, expressive, and both parties are fully involved, the tension will be relieved and it will be replaced by harmony completed in consummation. For Dewey, a consummatory experience is an experience endowed with an aesthetic quality. If we decided to give this aesthetic quality the name of beauty, which Dewey does not do explicitly, though in his works we could find certain suggestions accepting this course of reasoning, this beauty will not be the beauty of a male attracting a female, but the beauty of an experience which has been accomplished due to their mutual interaction. In other words it is not about the beauty of an object, but about the beauty of a process. The questions fundamental for evolutionary aesthetics - whether we have to do with beauty in itself (free of usefulness) or whether animals possess the sense of aesthetics, are removed to the background. Just like the question whether the aesthetics is a product of human culture exclusively.

Dewey does not introduce the opposition nature - culture, but he speaks about a continuum nature-culture. This is why the experiences taking place on various levels of this continuum assume the same pattern of interaction while the contents filling the experience or, most generally speaking, kinds of energy change. The perception of pleasure of consummation that is an experience of aesthetic brand is possible on each level, but the degree of its intensity, participation of consciousness and emotion, etc., will vary.

It seems that Dewey's theory of experience provides an effective tool to prove the fundamental for Darwin's theory thesis about continuity of aesthetic phenomena having their roots in pre-human world. It allows us to avoid the danger of both introducing a highly specialized concept of aesthetic beauty into the world of animals and limiting the perception of this beauty to the relations occurring in the narrow sphere of sexual selection within one species. A consummatory experience may also take place in an interaction of the leader with the herd, in the struggle for survival, building nests and foraging. If these actions finally assume the form of a harmonious experience, they will thereby achieve an aesthetic value. The orientation at practical goals that is present in them does not disturb their aesthetic character at all. 
The interpretive possibilities opened by Dewey's aesthetics are connected with the fact that this aesthetics was constructed totally on the margin of the mainstream of the modern aesthetics. The starting point for Dewey's aesthetic considerations was not the history of aesthetics but his philosophy of experience. This philosophy gave rise to the conception of an aesthetically branded experience in which the place of categories like the beauty of an object and attraction is taken by the category of the harmony of the course of interaction, aesthetic quality and consummation. This approach to the foundations of aesthetics does not limit it to the human dimension, opening the possibility of smooth entrance into other dimensions of the continuum of nature-culture. The difficulties of the evolutionary aesthetics consist in the fact that first we start from the dualistic opposition culture-nature and then we search for the ways of overcoming the gap that separates them. Dewey's thought strives to conceive the aesthetic phenomena not overcoming the dualism but ignoring it. It is not easy, considering the power of habit and the traditional thought patterns. 
"Biological Dimension of Art in the Pragmatist Aesthetics," in Annals for Aesthetics: Hellenic Society for Aesthetics - Fifty Years," (Athens: The Panayotis and Effie Michelis Foundation", 2011), Vol.1,219-229.

J. Dewey, Art as Experience (New York: Perigee Book, 1980), 14.

Ibid. p. 13,14

Ibid. p. 20

Ibid. p. 20, 21

Ibid. p. 19

I refer to this paper which I received from the author, then translated and published in Polish. Welsch developed some ideas of the paper in his book Blickwechsel. Neue Wege der Ästhetik (Reclam: Sttuttgart, 2012). especially in the chapter "Der animalische Ursprung der Ästhetik, p. 211-251.

Wilkoszewska, Krystyna. "Biological Dimension of Art in the Pragmatist Aesthetics." In Annals for Aesthetics: Hellenic Society for Aesthetics - Fifty Years, 219-229. Athens: The Panayotis and Effie Michelis Foundation,2011. 


\section{IDEJA “ZDRAVOG RAZUMA" PREISPITANA: DOPRINOS “AISTETIČKOM ZAOKRETU” ESTETIKE}

\section{Tanehisa Otabe}

Mi doživljavamo "aistetički zaokret" estetike koji se fokusira niti na naš umetnički doživljaj ili stvaranje, niti na ideju lepote, već na ulogu aistetike u našem estetskom razumevanju, odnosno na našoj aistetičkoj svesti našeg bića. Cilj ovog rada je da se preispita ideja "zdravog razuma" Aristotela i Kanta, u cilju reorganizacije i reanimacije njihovih uvida i na taj način doprinosu "aistetičkom zaokretu" estetike.

Na osnovu uobičajenih verovanja, postoje dva lanca u ideji "zdravog razuma": aristotelovska ideja o nečemu intra-subjektivnom što je zajedničko različitim čulima u jednom pojedincu i ciceronska ideja nečega inter-subjektivnog što je zajedničko različitim pojedincima. Za Kantov koncept zdravog razuma smatra se da pripada drugom lancu. Za razliku od takvih uverenja, ja tvrdim sledeće: prvo, da kod Aristotela već postoji produktivna klica druge vene i, drugo, da Kantova estetika vidno nasleđuje aristotelov concept "zdravog razuma".

Šta je problem u sensus communis u širem smislu je, dakle, naša aistetička svest našeg sopstvenog bića i života. U modernoj terminologiji, upravo aistetika garantuje "osećaj realnosti” (Hana Arent (Hannah Arendt)) nas i, samim tim, i sveta u kome živimo zajedno sa drugima.

KLJUČNE REČI: AISTETIČKI ZAOKRET ESTETIKE, ZDRAV RAZUM, PERCEPCIJA PERCEPCIJE, OSEĆANJE ŽIVOTA, ESTETSKA SVEST, KO-PERCEPCIJA

\section{ESTETSKO ISKUSTVO U KONTINUUMU PRIRODA-KULTURA. BIOLOŠKA DIMENZIJA PRAGMATIČKE ESTETIKE Krystyna Wilkoszewska}

Godine 1930. američki pragmatički filozof Džon Djui (John Dewey) uveo je u estetiku relativno novu ideju iskustva. Živeći u savremenom vremenu Djui je ponudio ne-modernistički način razmišljanja koji posebno u oblasti estetike izgleda kao adekvatniji našem vremenu u poređenju sa modernim idejama estetskog doživljaja i autonomije umetnosti. Nakon kratke prezentacije Djuieve filozofije estetike želim da pokažem njene unutrašnje dimenzije koje su u potpunosti razvijene danas: ekološke, evolucione i transhumanističke tendencije, iskustvo kao interakcija, soma i senzualna perspektiva.

KLJUČNE REČI: PRAGMATIZAM, SOMAESTETIKA, EVOLUCIJA, ŽIVOTINJSKA ESTETIKA

\section{STANJE ESTETIKE DANAS}

\section{Katya Mandoki}

U ovom radu moja zalaganja idu u smeru proširenja polje estetike ne samo izvan umetnosti i lepote, već i izvan svakodnevne estetike (ili prozaička) fokusirane na ljudsku osećajnost. To podrazumeva razmatranje senzibiliteta ili aesthesis u svim živim bićima kako bi se razumela beskonačnost bio-estetike. Te je deo ovog izlaganja zoo-estetika. Sve je više dokaza iz dana u dan koji potvrđuju postojanje senzibiliteta životinja, sposobnost da stvaraju, imitiraju, iskuse, izlože i izraze senzibilitet ili estetski ukus u različitim oblicima, te je teže negirati što više pratimo i svedočimo njihovom ponašanju. Štaviše, kako postoje različiti umetnički žanrovi, možemo jednako govoriti o sličnim žanrova u zoo-poetici, i to: a) muzički, b)vizualni (i arhitektonski i dekorativni), c) dramski, d) plesni.

Da li su ženke zaslepljene od strane muškog slepog miša ili ptičjom pesmom parenja? Da li paunice osećaju zadovoljstvo kada ugledaju rep muškog pauna? Kao što Najdžel (Nagel) pita 'kako je biti slepi miš?’ Zaista bih volela da znam kako je biti paunica. 